\title{
Pelaksanaan Program Badan Usaha Milik Desa (BUMDes) Di Kecamatan Jambi Luar Kota Kabupaten Muaro Jambi
}

\author{
M. Muslih ${ }^{1 *}$, Masriyani², Ryanda Putra Pratama ${ }^{3}$ \\ ${ }^{1,2,3}$ Fakultas Hukum, Universitas Batanghari Jambi, Indonesia \\ *Correspondence email: muslih.ubr@gmail.com; masriyani@unbari.ac.id
}

\begin{abstract}
Abstrak. Untuk melaksanakan pembangunan nasional pada satuan wilayah paling kecil yang disebut dengan Desa ini, diperlukan upaya untuk mencapai kesejahteraan masyarakat Desa dengan menggali sumber-sumber Pendapat Asli Desa (PADes) yang ada. Salah satu bentuk sumber dari PADes yaitu berasal dari keuntungan yang hasilkan oleh Badan Usaha Milik Desa. Desa dapat mendirikan Badan Usaha Milik Desa yang disebut BUMDes. Hal ini bertujuan agar masyarakat Desa mampu mengembangkan aset-aset yang dimiliki oleh Desa untuk menjadi salah satu sumber PADes, sebagaimana diatur dalam Peraturan Menteri Desa Nomor 4 tahun 2015 tentang Pendirian, Pengurusan, dan Pengelolaan, dan Pembubaran Badan Usaha Milik Desa yang selanjutnya akan disebut Permendes BUMDes. Pelaksanaan kegiatan BUMDes di Kecamatan Jambi Luar Kota menjadi penelitian pada penulisan skripsi ini dengan fokus permasalahan terhadap implementasi kegiatan BUMDes di beberapa desa di Kecamatan Jambi Luar Kota yaitu Desa Sungai Duren, Desa Mendalo Laut dan Desa Senaung berdasarkan Peraturan Menteri Desa Nomor 4 Tahun 2015 dan faktor-faktor penghambat dalam kegiatan BUMDes di Kecamatan Jambi Luar Kota. Metode penelitian yang digunakan adalah yuridis empiris dengan analisis data berasal dari hasil wawancara dengan responden/narasumber terkait kegiatan BUMDes di Kecamatan Jambi Luar Kota. Sehingga hasil penelitian ini akan fokus pada implementasi kegiatan BUMDes di Kecamatan Jambi Luar Kota.
\end{abstract}

Kata Kunci: BUMDes; implementasi; kesejahteraan

Abstract. To carry out national development in the smallest area unit called the Village, an effort is needed to achieve the welfare of the Village community by exploring the existing Village Original Opinion sources (PADes). One form of the source of PADes is derived from the profits generated by the Village-Owned Enterprises. Villages can establish village-owned enterprises called BUMDes. It aims to make the village community able to develop assets owned by the village to become one of the sources of the PADes. The implementation of BUMDes activities in the Jambi Luar Kota sub-district became a research in writing this thesis with a focus on the problem of the implementation of BUMDes activities in several villages in the Jambi Luar Kota sub-district namely Sungai Duren Village, Mendalo Laut Village and Senaung Village based on Village Minister Regulation Number 4 of 2015 and factors inhibitors in BUMDes activities in Jambi Luar Kota sub-district. The research method used is empirical juridical, data analysis derived from interviews with respondents / resource persons related to BUMDes activities in Jambi Luar Kota District. So the results of this study will focus on the implementation of BUMDes activities in the Jambi Luar Kota subdistrict.

Keyword: BUMDes; implementation; welfare

\section{PENDAHULUAN}

Pembangunan nasional bertujuan untuk mewujudkan masyarakat yang adil dan makmur baik secara spiritual maupun material dengan berpedoman pada Pancasila dan Undang Undang Dasar Negara Republik Indonesia. Sebagai bentuk pengamalan Pancasila, pembangunan nasional harus dilakukan diseluruh aspek kehidupan bangsa dan negara yang diselenggarakan oleh masyarakat bersama-sama dengan pemerintah. Agar kegiatan masyarakat dan pemerintah dapat terselenggarakan, tentu masyarakat sebagai pelaku utama pembangunan wajib untuk diarahkan, dibimbing dan dilindungi oleh pemerintah agar tujuan pembangunan nasional dapat terealisasikan dengan ditunjang dari masyarakat dan pemerintah.

Dalam konteks pemerintahan daerah tentunya sangat perlu dilakukan bimbingan dan arahan dari pemerintah daerah kepada masyarakat dalam upaya untuk meningkatkan kesejahteraan masyarakat. Pemerintahan daerah dalam lingkup kecil yaitu Desa, merupakan pemerintahan yang sangat dekat hubungannya dengan masyarakat sehingga pengaturan secara formal dan operasional perlu diatur oleh Pemerintah Pusat. Untuk menjawab itu, Presiden bersama dengan DPR telah menerbitkan sebuah Undang-Undang tentang Desa pada tahun 2014, yaitu Undang-Undang Nomor 6 Tahun 2014 tentang Desa (yang selanjutnya disebut UU Desa). Secara umum, UU Desa ini membahas tentang Desa dimulai dari definisi-definisi tentang Desa, siapa pemerintah Desa, hak dan kewajiban Desa, keuangan Desa, terbentuknya dan hapusnya Desa serta lebih banyak lagi.

Untuk melaksanakan pembangunan nasional pada satuan wilayah paling kecil atau Desa ini, diperlukan upaya untuk mencapai kesejahteraan masyarakat Desa dengan menggali sumber-sumber Pendapat Asli Desa (PADes) yang ada. Salah satu bentuk dari sumber dari PADes itu adalah adanya Badan Usaha Milik Desa (selanjutnya disebut BUMDes). Badan Usaha Milik Desa merupakan badan usaha yang seluruh atau sebagian besar modalnya dimiliki oleh 
Desa melalui penyertaan langsung yang berasal dari kekayaan Desa yang dipisahkan guna mengelola aset, jaya pelayanan dan usaha lainnya untuk sebesar-besarnya kesejahteraan masyarakat Desa.

Sebagai upaya peningkatan kesejahteraan masyarakat Desa dengan membentuk BUMDes, sudah diatur pada UU Desa BAB X Pasal 87 sampai Pasal 90 tentang Badan Usaha Milik Desa. Selain itu untuk lebih jelas lagi, maka pemerintah membentuk sebuah Peraturan Pemerintah Nomor 43 tahun 2014 tentang Peraturan Pelaksanaan Undangundang Nomor 6 tahun 2014 tentang Desa, yang mana pada BAB VIII Pasal 132 sampai 142 menjelaskan tentang BUMDes. Kemudian untuk lebih kepada pelaksanaan teknis, Desa dapat mempedomani Peraturan Menteri Desa Nomor 4 tahun 2015 tentang Pendirian, Pengurusan, dan Pengelolaan, dan Pembubaran Badan Usaha Milik Desa yang selanjutnya akan disebut Permendes BUMDes.

Seluruh Desa di wilayah Kesatuan Republik Indonesia dapat membentuk BUMDes, sepeti yang disebutkan pada Pasal 87 ayat (1) UU Desa, hal ini bertujuan agar masyarakat Desa mampu mengembangkan aset-aset yang dimiliki oleh Desa untuk menjadi salah satu sumber PADes. Dan Dalam penelitian ini, penulis mengambil sampel Desa di Kecamatan Jambi Luar Kota, Kabupaten Muaro Jambi, Provinsi Jambi. Sebagaimana diketahui bahwa Kecamatan Jambi Luar Kota terdiri dari 19 (sembilan belas) Desa ${ }^{1}$.

Berdasarkan hasil wawancara dengan Sekretaris Camat hampir seluruh Desa mempunyai minimal satu Badan Usaha Milik Desa. Untuk lebih menjawab ini maka dari 19 (sembilan belas) Desa tersebut akan di ambil sampel Desa sebanyak 7 Desa yang memiliki Badan Usaha Milik Desa yang berjalan dengan sangat baik dan menghasilkan keuntungan bagi Desa, kemudian desa yang memiliki BUMDes namun tidak ada jelas administrasinya, dan ada juga BUMDes yang ada namun tidak berjalan sama sekali, lalu Desa yang tidak mempunyai sama sekali. Terhadap yang telah dilakukan, ditemui kendala-kendala pada penyelenggaraan BUMDes ini seperti administrasi dan struktur organisasi Badan Usaha Milik Desa yang belum terbentuk.

\section{METODE}

Penelitian dan penulisan karya ilmiah ini merupakan penelitian penelitian hukum yuridis empiris, adalah pendekatan penelitian yang dimaksudkan untuk mengetahui dan melakukan pengumpulan data lapangan sejauh mana implementasi kegiatan, pelaksanaan kebijakan dan faktor-faktor penghambat yang dihadapi dalam Pelaksanaan Program Badan Usaha Milik Desa (Bumdes) Di Kecamatan Jambi Luar Kota Kabupaten Muaro Jambi. Dalam usaha mendekati pokok permasalahan dalam penelitian ini, penulisan menggunakan type penelitian yang bersifat deskriptif, yaitu menggambarkan bagaimana implementasi kegiatan Bumdes tersebut.

Untuk memperoleh berbagai data dan informasi di lapangan, maka penulis menggunakan pengumpulan data melalui wawancara, dilakukan dengan daftar pedoman wawancara yang telah disusun terlebih dahulu kepada responden dalam bentuk wawancara tidak terarah pada responden, dan bentuk dokumentasi adalah data yang diperoleh melalui bentuk-bentuk tulisan yang terkait dengan penelitian ini, baik berupa peraturan perundang-undangan maupun pustaka lainnya.

Selanjutnya agar penelitian ini tidak meluas ke segala permasalahan maka penulis membatasi ruang lingkup penelitian terhadap pelaksanaan BUMDes terhadap 7 desa di Kecamatan Jambi Luar Kota, dan menganalisa hambatan yang ditemui dalam pelaksanaan BUMDes. Hasil penelitian dituangkan dalam bentuk karya ilmiah yang bersifat deskriptif analitis sehingga dapat memberikan gambaran yang jelas, menyeluruh dan sistematis mengenai permasalahan yang dibahas.

Data yang terkumpul dikualifikasi sesuai dengan karateristiknya, setelah itu kemudian data dilakukan analisis secara kualitatif, yaitu dari data yang disajikan kemudian ditarik kesimpulan dengan menggunakan metode indukatif. Yaitu suatu tehnik penarikan kesimpulan dari hal-hal yang bersifat umum pada kesimpulan yang bersifat khusus.

\section{HASIL DAN PEMBAHASAN}

\section{Pelaksanaan BUMDes di Kecamatan Jambi Luar Kota.}

Pembahasan masalah pelaksanaan BUMDes di Kecamatan Jambi Luar Kota ini akan dikelompokkan keda dua kajian pertama, kajian dari aspek kelembagaan BUMDes, kedua kajian dari aspek pencapaian tujuan keberadaan BUMDes.

\section{Pelaksanaan BUMDes dilihat dari Aspek Kelembagaan}

Dilihat dari aspek kelembagaan maka gambaran BUMDes di Kecamatan Jambi Luar Kota dapat dilihat dari Tabel di bawah ini:

${ }^{1}$ Wawancara dengan Kalduni sebagai Sekretaris Camat Kecamatan Jambi Luar Kota, pada hari Senin, 10 Februari 2020 , pukul 10.29 WIB. 
M. Muslih et al, Pelaksanaan Program Badan Usaha Milik Desa (BUMDes) Di Kecamatan Jambi Luar Kota Kabupaten Muaro Jambi

\begin{tabular}{|c|c|c|c|c|}
\hline No. & Nama Desa & $\begin{array}{c}\text { Pembentukan/ Nama } \\
\text { dan Struktur BUMDes }\end{array}$ & Unit Usaha & Kondisi/ Status \\
\hline 1 & Pematang Gajah & $\begin{array}{l}\text { 2020/ belum memiliki } \\
\text { nama dan } \\
\text { Bumdes }\end{array}$ & unit usaha Jasa Air Minum isi Ulang & $\begin{array}{l}\text { belum berjalan dan } \\
\text { belum memberikan } \\
\text { hasil }\end{array}$ \\
\hline 2 & Simpang Sungai Duren & $\begin{array}{lrr}2018 / & \text { "Sinar } & \text { Muya } \\
\text { Abadi" } & \text { dan } & \text { telah } \\
\text { memiliki } & \text { pengurus } \\
\text { Bumdes. } & & \end{array}$ & $\begin{array}{l}\text { a.Unit Usaha Jasa Pembayaran } \\
\text { Rekening Listrik, PDAM, Telephone, } \\
\text { HandPhone prabayar, TV } \\
\text { beralangganan, BPJS Kesehatan, } \\
\text { Pembayaran Multifinance } \\
\text { b.Unit Usaha Pengangkutan Sampah } \\
\text { c.Unit Usaha Simpan Pinjam }\end{array}$ & $\begin{array}{lr}\text { kegiatan berjalan } \\
\text { dan sudah } \\
\text { menghasilkan }\end{array}$ \\
\hline 3 & Muhajirin & $\begin{array}{l}\text { 2020/ belum ada nama } \\
\text { dan belum ada pengurus } \\
\text { Bumdes }\end{array}$ & tidak ada & $\begin{array}{l}\text { belum ada kegiatan } \\
\text { dan belum } \\
\text { mengahsilkan }\end{array}$ \\
\hline 4 & Pematang Jering & 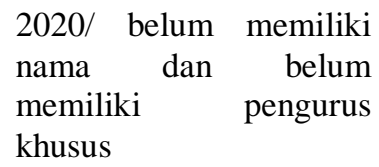 & $\begin{array}{l}\text { Unit Usaha Penyediaan Makan Ikan } \\
\text { (poor). }\end{array}$ & $\begin{array}{l}\text { kegiatan berjalan } \\
\text { dan menghasilkan } \\
\text { keuntungan }\end{array}$ \\
\hline 5 & Sungai Duren & 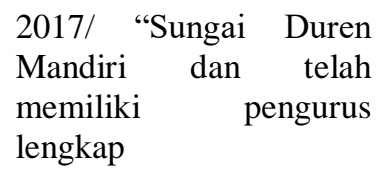 & $\begin{array}{l}\text { a.Unit Usaha Pengangkutan Sampah } \\
\text { b.Unit Usaha Persewaan Tenda } \\
\text { c.Unit Usaha Pengelolaan Pasar Desa }\end{array}$ & $\begin{array}{l}\text { kegiatan berjalan } \\
\text { dan menghasilkan } \\
\text { keuntungan }\end{array}$ \\
\hline 6 & Mendalo Laut & 2017 & $\begin{array}{l}\text { a.Unit Usaha Penambangan Pasir } \\
\text { b.Unit Usaha Simpan Pinjam } \\
\text { c.Unit Usaha kerajinan batik dan jahit } \\
\text { d.Unit Usaha makanan ringan }\end{array}$ & $\begin{array}{l}\text { kegiatan belum } \\
\text { optimal dan belum } \\
\text { memberikan hasil }\end{array}$ \\
\hline 7 & Senaung & $\begin{array}{l}\text { 2017/ } \\
\text { Mandiri" } \\
\text { memiliki } \\
\text { Bumdes. }\end{array}$ & $\begin{array}{l}\text { a.Unit Usaha Sewa Tenda } \\
\text { b.Unit Usaha Sewa Hantaran } \\
\text { c.Unit Usaha Sewa Kursi } \\
\text { d.Unit Usaha Sewa Kain Slayer } \\
\text { e.Unit Usaha Sewa Kamera/ Shooting }\end{array}$ & $\begin{array}{lr}\text { Kegiatan } & \text { sudah } \\
\text { berjalan } & \text { dan } \\
\text { menghasilkan } & \\
\text { keuntungan } & \end{array}$ \\
\hline
\end{tabular}

Sumber: Hasil penelitian (wawancara dan pengamatan)

Badan Usaha Milik Desa Pematang Gajah, secara juridis BUMDes ini telah dibentuk pada akhir Tahun 2019, akan tetapi alokasi permodalan dan struktur pengurusnya baru akan disusun dan ditetapkan pada Tahun 2020. Namun demikian terkait dengan adanya kebijakan pemotongan bebagai anggaran untuk penanganan akibat covid 19 ini maka realisasi anggaran yang akan dialokasikan sebagai modal awal BUMDes tersebut tertunda, akibatnya kegiatan operasional jasa penyediaan air isi ulang belum dapat direalisasikan.

Badan Usaha Milik Desa Simpang Sungai Duren dengan nama Sinar Mulya Abadi yang didirikan sejak Tahun 2018 ini melayani kurang lebih 3270 jiwa. Karakter masyarakat Simpang Sungai Duren ini merupakan masyarakat semi perkotaan dimana "budaya instan dan pragmatis tercermin dalam kehidupannya" untuk itu bidang kegiatan atau jasa yang disediakanpun menyesuaikan kebutuhan masyakata seperti Unit Usaha Jasa transaksi (Pembayaran Rekening Listrik, PDAM, Telephone, HandPhone prabayar, TV beralangganan, BPJS Kesehatan, Pembayaran Multifinance). Unit Usaha Pengangkutan Sampah, Unit Usaha Simpan Pinjam.

Pelaksanaan dan perkembangan dari seluruh unit usaha di Simpang Sungai Duren saat ini agak kurang memuaskan seiring dengan perkembang dan kemajuan transaksi elektronik yang dapat dilakukan oleh masyarakat dalam jasa transaksi pembayaran berbagai rekening. Sedangkan jasa Pengangkutan Sampah Masyarakat dan Simpan Pinjam meskipun secara finansial belum memberikan tambahan hasil yang signifikan bagi Desa, namun telah memberikan dan mencipatakn lapangan pekerjaan begi beberapa rumah tangga. Sedangkan unit simpan pinjam meskipun terbatas menurut informasi dari pengurus BUMDes telah dapat membantu sekaligus mengurang ketergantuangan sebagain masyarakat (kurang lebih 50 nasabah) terhadap jasa simpan pinjam perorangan yang bunganya relative tinggi (semacam "lintah darat")

Badan Usaha Milik Desa Muhajirin sampai saat ini baru samapai tahap kesepakatan warga untuk membentuk BUMDes. Hal ini disebabakan pada Tahun 2019 saat warga masyarakat mendukung penuh dan berkeinginan memiliki badan usaha, jabatan kepala desa masih dipegang oleh pajabat kepala desa, dan setelah Kepala Desa Muhajirin terpilih dan ditetapkan justru giliran masa jabatan BPD yang akan berakhir, sehingga warga mengingnkan menunggu Anggota BPD baru terpilih yang akan bersama-sama dengan Kepala Desa untuk membentuk BUMDes . namun seperti 
kita ketahui bahwa berkembangnya virus covid dan kebijakan pemerintah pusat dalam menanggulangi dampak negative dibidang ekonomi menyebabkan tertunda lagi pembentrukan BUMDes tersebut.

Badan Usaha Milik Desa Pematang Jering baru dibentuk pada Tahun 2020, bahkan belum memiliki pengurus definitive (masih dikendaliakan oleh Kepala Desa). Namun demikian Bumdes tersebut telah memberikan hasil dan keuntungan yang signifikan kurang lebih 15\% dari Modal usaha awal. Adapun jasa yang ditawarkan kepada masyarakat adalah penyediaan makanan ikan (poor). Desa Pematang Jering dengan jumlah penduduk 1235 jiwa. Secara geograifis terlatak pada pinggir sungai batanghari. Kegiatan masyarakatnya adalah budi daya ikan (mayoritas ikan nila). Di desa ini terdapat kurang labih 5000 keramba dan menghasilan ikan segar rata-rata 12 ton sehari yang dikirim ke Pasar Angsoduo. Sejatinya market (pasar) sebagai titk temu penawaran dan permintaan di desa Pematang Jering ini sudah terbentuk sehingga keberadaan BUMDes di desa ini sekedar ikut ambil bagian guna penyediaan kebutuhan pakan ikan guna menghidupi dan menggerakkan aktifitas perikanan dari kurang lebih 5000 keramba tersebut. Sehingga wajar jika dijelaskan bahwa meski baru tahun ini BUMDes dibentuk dan beroperasi sudah memberikan hasil dan keuntungan yang signifikan. Sehubungan dengan hal tersebut tahun depan direncanakan Desa Pematang Jering akan menambah modal kerja kurang lebih 100 juta melalaui APBDes Tahun Anggaran 2021.

Badan Usaha Milik Desa Sungai Duren yang diberi nama Sungai Duren Mandiri ini dibentuk Tahun 2017 dan telah memiliki pengurus yang definitive. Layanan yang disediakan oleh Bumdes Sungai Duren Mandiri ini meliputi Unit Usaha Pengangkutan Sampah, Unit Usaha Persewaan Tenda dan kelengkapan lainnya serta Unit Usaha Pengelolaan Pasar Desa. Desa Sungai Duren memiliki wilayah relative luas dengan jumlah penduduk kurang lebih 3031 jiwa, dengan tradisi seperti tradisi masyarakat desa-desa lainnya yakni banyak melakukan kegiatan adat/ syukuran di berbagai ivent seperti, pernikahan, khitan, cukuran bayi, ibadah haji dan atau umroh semua itu peringati dan dihadiri oleh masyarakat relative banyak. Aktifitas atau acara ini tentu memerluka sarana untuk menampung massa yang relative banyak. Untuk itu usaha persewaan tenda, kursi dan kelengkapan lainnya merupakan langkah yang tepat bagi Bumdes desa ini. Desa Sungai Duren meruakan pintu masuk ke daerah-daerah lain menjadikan desa ini sebagai aksesbilitas, sehingga wajar jika di desa ini terdapat pasar yang relative besar.

Aktifitas pasar tersebut di atas tentunya melibatkan banyak pihak, maka Bumdes mengambil manfaat dengan mengurus dan mengelola penarikan retribusi lapak dan retribusi parkair. Limbah akibat aktifitas pasar ini pun juga diurus dan pembersihannya dilakukan oleh bumdes selain mengangkut sampah dari rmah tanga-rumah tangga di desa Sungai Duren. Dari berbagai aktifitas tersebut BUMDes telah menyumbangkan penghasilan kepada desa sekaligus memberikan lapangan pekerjaan bagi masyarakat Sungsi Duren.

Badan Usaha Milik Desa Senaung, ini relative sudah lama dibentuk yakni Tahun 2017. Bumdes ini melayani kurang lebih 2732 jiwa, dalam menentukan jenis usaha tidak terlepas dari hal-hal yang sangat dan sering diperlukan oleh masyarakat setempat seperti sewa tenda, jasa paket hantaran, sewa kain slayer dan kamera untuk shooting merupakan satu kesatuan yang diperlukan oleh masyarakat dalam menjalankan tradisi/ adat "pesta perkawinan" yang relative tinggi frekwensinya, bahkan dalam satu desa kadang kadang terdapat lebih dari 2 keluarga yang malaksanakan pesta di hari yang sama. Kegiatan dan jenis usaha seperti yang dipilih oleh Desa Senaung secara otomatis menyerap tenaga kerja karena layanan ini semua dilaksanakan oleh masyarakat Senaung sendiri. Tenaga yang dipergunakan relative tidak memerlukan ketrampilan khusus, seperti persewaan Tenda dan kursi dimana kegiatan ini memerlukan tenaga yang relative banyak kelompok ini paling tidak memerlukan $4 \mathrm{~s} / \mathrm{d} 5$ orang tenaga termasuk mobilitas/ tranportasi. sedangkan untuk tenaga sewa hantara, make-up dan camera shooting memerlukan ketrampilan khsusus untuk itu diperlukan beberapa pelatihan.

Dilihat dari aspek Kelembagaan BUMDes maka dari 7 desa yang diteliti semua desa telah memiliki BUMDes. Dilihat dari pembentukan dan penetapannya BUMDes tersebut terbagi dalam 2 kategori, yakni pertama Pembentukan BUMDes sudah ditetapkan melalui Peraturan Desa sebagaimana diatur dalam ketentuan Pasal 4 ayat (1) Permendesa PDTT No. 4 Tahun 2015, sebagai contoh BUMDes Desa Sungai Duren dibentuk dan ditetapkan melalui Peraturan Desa Sungai Duren No. 6 Tahun 2017, begitu juga halnya dengan pembentukan BUMDes di Desa Simpang Sungai Duren, Desa Senaung, Desa Pematang Jering dan Desa Mendalo Laut telah ditetapkan dengan peratuiran desa masingmasing.

Kategori kedua BUMDes yang pembentukannya baru pada tahap kesepakatan Musyawarah Desa sebagaimana diatur dalam Pasal 5 ayat (1) akan tetapi belum dituangkan dalam bentuk Peraturan Desa sebagaimana dikehendaki dan diatur dalam Pasal 6 ayat(3) Permendesa PDTT. (BUMDes Desa Pematang Gajah dan Desa Muhajirin).

Dilihat dari kemandirian pengelolaan Bumdes sebagian besar telah memenuhi amanat Pasal 9 Permendesa BUMDes yang memisahkan organisasi pengelolaan Bumdes dengan organisasi Pemerintahan Desa, BUMDes di Desa Senaung, Desa Sungai Duren, dan Desa Simpang Sungai Duren sudah memiliki kepengurusan definitive dengan struktur sebagaimana diatur dalam Pasal 10 ayat (1) Permendes BUMDes. Dimana struktur BUMDes terdiri dari Penasehat, Pelaksana operasional dan Pengawas. Di sisi lain BUMDes Desa Pematang Jering masih dikendalikan langsung oleh Kepala Desa. Hal ini terjadi karena memang pembentukan BUMDesnya relative baru, sehingga pembentukan kepengurusan dan tempat BUMDes belum dipersiapkan, sampai saat ini kantor Bumdes masih menyatu 
dengan Balai Desa dan pengelolaannya juga masih langsung dilakukan oleh Kepala Desa. Namun demikian menurut Kepala Desa Pematang Jering akan segera dibentuk kepengurusan yang definitive dan tempat yang representative.

BUMDes desa Pematang Gajah dan desa Muhajirin belum ada pengurusnya, hal ini sebagai konsekwensi logis karena pembentukan BUMDes-nya belum dikemas dalam Peraturaaaan Desa yang didalamnya terdapat unsur pengurus.

Adapun bidang atau jenis usaha yang ditetapkan dan dijalankan oleh BUMDes di desa-desa yang disurvai besifat variatif, pada umumnya mengacu dan berpedoman pada jenis usaha yang diatur dalam Permendesa, atau setidak-tidaknya tidak bertentangan dengan ketentuan yang diatur dalam pasal 19 s/d 24 Permendesa BUMDes.

\section{Pelaksanaan BUMDes dilihat dari Tujuan Pendirian BUMDes}

Tujuan didirikannya BUMDes sebagaimana diatur dalam Pasal 3 Permendesa BUMDes antara lain meningkatkan perekonomian Desa, mengoptimalkan aset Desa agar bermanfaat untuk kesejahteraan Desa, menciptakan peluang dan jaringan pasar yang mendukung kebutuhan layanan umum warga, membuka lapangan kerja dan meningkatkan pendapatan masyarakat Desa dan Pendapatan Asli Desa, dll.

Tujuan pendirian BUMDes tersebut jika dilihat di lapangan maka, BUMDes Desa Sungai Dure, Desa Simpang Sungai Duren dan Desa Senaung ini relative memerlukan tenaga kerja yang banyak, mengingat jenis kegiatan yang memerlukan tenaga manusia seperti seperti persewaan tenda dan kelengkapannya untuk keperluan pesta, pemungutan retribusi lapak pasar dan parkir di pasar dan pengangkutan sampah, Kegiatan yang sama juga di Desa Simpang Sungai Duren, dengan pengangkutan sampah, pelayanan jasa pembayaran angsuran, premi, retribusi, simpan pinjam Kegiatan ini tentu menyerap tenaga kerja lokal untuk mengerjakannya baik memungut, mengangkut. Selain itu juga memanfaatkan kendaraan (lengkap dengan sopirnya) guna moboilitas baik sampah maupun pengangutan tenda dan kelengkapanya dari gudang ke rumah tangga penyewa. Terserapnya tenaga kerja otomatis akan mengasilkan upah yang berdampak pada peningkatan daya beli kjeluarga pekerja. Hal ini sedikit mendorong naik tingkat kesejahteraannya.

Khusus BUMDes Desa Pematang Jering ini agak unik, karena secara kelembagaan BUMDes ini belum ideal, tetapi dari aspek operasional cukup baik, mengingat potensi pasar di desa ini sangat besar. Keberadaan budidaya ikan keramba oleh masysrakat yang jumlahnya kurang leboih 5000 keramba ini merupakan pasar yang sangat besar. Uuntuk itu maka meski baru beberapa bulan beroperasi BUMDes telah memberikan hasil yang signifikan. Kondisi ini juga berdampak pada kemudahan masyarakat petani untuk memperolaeh pakan dan di sisi lainya membrikan tambahasan pendapatan asli desa Pematang Jering. Sementara itu untuk BUMDes 3 desa yakni Desa Mendalo Laut, Desa Muhajirin dan Desa Pematang Gajah, belum dapat mewujudkan tujuan didirikannya BUMDes, Hal ini disebabkan BUMDes ketiga desa tersebut belum dapat beroperasi.

\section{Hambatan dalam Pelaksanaan BUMDes di Kecamatan Jambi Luar Kota.}

Hambatan/ kesulitan dan dinamika dalam pelaksanaan sebuah program merupakan suatu yang tidak dapat dielakkan demikian juga dalam pelaksaan BUMDes di desa-desa yang menjadi objek penelitian ini dimana BUMDesnya juga mengalami beberapa kendala dalam operasionalnya.

Sebagaimana telah disebutkan sebelumnya bahwa dari 7 BUMDes yang diteliti baru empat (4) BUMDes (Desa Sungai Duren, Simpang Sungai Duren, Senaung dan Pematang Jering) yang melakukan kegiatan dan programnya, sedangkan BUMDes di tiga (3) Desa yakni Pematang Gajah, Mendalo Laut dan Muhajirin belum beroperasi sebagaimana mestinya.

Pada umumnya yang belum beroperasi/ menjalankan programnya ini disebabkan adanya kebijakan pemerintah terkait dengan penggunaan berbagai anggaran untuk penanggulangan dampak negative pandemic covid 19. Kebijakan ini membuat desa-desa yang BUMDesnya belum beroperasi/ berjalan tidak berani menganggarkan dana untuk persiapan operasional BUMDes di desanya. Hal ini terjadi di Pematang Gajah dan Muhajirin. Kegagalan awal pelaksanaan program tersebut pada giliranya mempersulit untuk mendapatkan klesepakatan warga ketika ada keinginan untuk merevitalisasi program kegiatan, apalagi ditambah dengan berbagai pembatasan anggaran. Hal ini membuat berbagai pihak pemangku kepentingan BUMDes menjadi tidak "percaya diri”.

Sedangkan terhadap BUMDes yang telah beroperasi/ menjalankan kegiatannya juga tidak lepas dari berbagai kendala dan kesulitan, seperti yang dialami oleh BUMDes yang menyediakan unit usaha pengangkutan sampah, mengalami kesulitan karena msih adanya warga yang tidak ikut menjadi pelanggan tetapi mereka membuang sampah dengan cara menitip ditempat warga yang menjadi pelanggan (padahal retribusinya hanya $\mathrm{Rp} 20.000$,- setiap keluarga, akibatnya jumlah uang yang terkumpul dengan akumulasi tumpukan sampah manjadi tidak seimbang, artinya sampahnya sangat banyak tetapi hasil iurannya relative kecil. Hal-hal seperti ini memang perlu mendapat perhatian dari para pemanglu kepentingan dan tokoh-tokoh masyarakat didesa setempat.

Unit usaha yang bergerak dibidang jasa pembayaran angsuran, retribusi, premi dan lain sebagainya juga mengalami penurunan konsumen seiring dengan perubahan sosial dimana transaksi digital ( $e$ banking) juga sudah 
memasuki kehidupan warga di desa. Akibatnya beberapa BUMDes terpaksa mengurangi karyawannya guna menyeimbangkan antara masukan dan pengeluaran berupa honor/ upah.

Secara umum kesadaran hukum masyarakat tentang makna, tujuan dan mafaat dari BUMDes masih belum difahami dengan baik dan benar. Pengetahuan dan pemahaman bahwa jika segala sesatu kebutuhan itu dapat dipenuhi oleh potensi dan sumber daya lokal maka uang yang beredar tidak akan keluar, dengan demikain maka perputaran uang diwilayah domestic akan meningkat. Dalam keadaan seperti inilah tingkat kesejahteraan sampai tingkat tertentu berpotensi untuk lebih mudah ditingkatkan.

\section{SIMPULAN}

1. Berdasarkan uraian hasil penelitian di atas dapat disimpulkan bahwa pelaksanaan BUMDes di Kecamatan Jambi Luar Kota secara umum sudah terlaksana. Meskipun kalau dilihat dari aspek kelembagaan masih ada BUMDes yang dibentuk berdasarkan kesepakatn warga masyarakat dan belum dibentuk berdasarkan PerDes. Dilihat dari aspek tujuan didirikannya BUMDes mayoritas sudah BUMDes sudah operasional dan menghasilkan, namun masih ada yang belum berjalan.

2. Hambatan pelaksanaan BUMDes di Kecamatan Jambi Luar Kota antara lain disebabkan adanya kebijakan pengalihan sebagain anggaran guna menanggulangi dampak negative pandemic covid 19, kurangnya kesadaran hukum masyarakat dalam mendukung suksesnya program BUMDes dan adanya perubahan perilaku terkait dengan transaksi elektronik

\section{DAFTAR PUSTAKA}

Undang Undang Dasar Negara Republik Indonesia Tahun 1945;

Undang Undang Nomor 32 Tahun 2004 tentang Pemerintahan Daerah;

Undang Undang Nomor 12 Tahun 2011 tentang Pembentukan Peraturan Perundang-undangan

Undang Undang Nomor 23 Tahun 2014 tentang Pemerintahan Daerah

Undang Undang Nomor 6 Tahun 2014 tentang Desa;

Peraturan Pemerintah Nomor 43 Tahun 2014 tentang Peraturan Pelaksanaan Undang Undang Nomor 6 Tahun 2014 tentang Desa;

Peraturan Menteri Desa, Pembangunan Daerah Tertinggal dan Transmigrasi Republik Indonesia Nomor 4 Tahun 2015 tentang Pendirian, Pengurusan dan Pengelolaan dan Pembubaran Badan Usaha Milik Desa

Peraturan Menteri Dalam Negeri Nomor 84 Tahun 2015 tentang Susunan Organisasi dan Tata Kerja Pemerintahan Desa 